\title{
THE BIRTH OF 'ARROW OF TIME' SCIENTIFIC KNOWLEDGE ${ }^{2}$
}

ABSTRACT: This article analyzes the consequences of 'arrow of time' expressed in the becoming complex socium that are seen as new challenges for the existing knowledge. The author argues that the effect of 'arrow of time' should be extended to the non-linear dynamics of scientific knowledge in general and sociological knowledge in particular, stating that the 'arrow of time' scientific knowledge is being born and it is based on new synthesis of sciences. In this regard, there analyzed the 'turns in sociology' - qualitative changes in its interaction with other sciences borrowing their knowledge - as separate terms as well as concepts which are then filled with the actual sociological content. The answer to these encountered challenges the author sees in humanistic turn involving a synthesis of social, hard and humane sciences and their development in the direction of searching for new forms of humanism based on men's existential needs.

KEY WORDS: Social and cultural dynamics, 'arrow of time', complex society, turbulence, reflexivity, non-linearity. scientific knowledge, humanistic turn.

\footnotetext{
sociol7@yandex.ru
}

2 Рад је примљен 10. октобра 2014, а прихваћен за објављивање на састанку Редакције 3борника одржаном 25. децембра 2014. 
Nowadays a new social reality in the form of a complex socium is being produced. On a global and local levels the world faces the increasing acceleration of social and cultural dynamics of socium. The Nobel prize-winner I. Prigogine has worked out the theory of 'arrow of time' according to which all the matter (this concerns as material as social worlds) is being developed increasingly quicker and quicker. Besides, the dynamics becomes more and more complex, including points of bifurcation, traumas, crises, and vulnerabilities. But uncertainties and turbulences that have come into our life do not presuppose a pure chaos, rather non-linear developing social systems. Thus, I. Prigogine speaks about emergent, dynamic and selforganizing systems interacting in ways that heavily influence the probabilities of later events [Prigogine, 1997]. In our opinion, the effect of 'arrow of time' should be extended to the dynamics of scientific knowledge in general and sociological knowledge in particular. We see the birth of a new type of scientific knowledge based on 'arrow of time' effects.

The $11^{\text {th }}$ European Sociological Association Conference (Italy, Turin, 2013) was held under the theme: "Crisis, Critique and Change". The forum organizers pushed into the center of scientific discussions the problems of modern global crisis bearing in mind that it encourages the critical revision of the current sociological knowledge and working out new, more valid approaches, original theoretical and methodological tools allowing more adequately to estimate the essence of changes in the world. Frank Welz, the Chair of the Conference Programmme Committee, argued: "The present crisis is multi-faced. It is not just a debt crisis, but also a political and social crisis... What is behind the crisis? Two processes are at work. First, there has been a systemic transformation driving the shift of power from public to private power and adapting the state to capital markets. But second, there has been a proliferation of vital critique too. Think about the deepening of existing divides. The Occupy protests, the social uprising in the Arab Spring, the unrest in Greece, and discontent in other European countries are all indicative of a reconfiguration of the link between crisis and critique" [Welz, 2013] .

Taken together these complex processes inevitably generate new reflections of the existing knowledge. People have to live without stable orientations, long-living factors of order, commonly accepted traditions and authorities with regard to the scientific tools that have previously quite well served for many years. Even scientific reference groups lose their power to represent the truth. The consequences of 
'arrow of time' inevitably spawn anomalies. In this context scientific knowledge is rapidly becoming obsolete. To keep pace with the adequate analysis of the accelerating complex socium scientists express "the will to truth" and try to differentiate true and false [Foucault, 1976]. A dramatic shift in their thinking focuses on increase of critique and on acceleration of the production of innovative knowledge: now they have not to clarify or improve the existing scientific tools, but from the standpoint of innovative theorizing and new type of sociological imagination to rediscover social reality that constantly grows in strength and depth. The ongoing need to rethink social realities and to interpret daily appearing anomalies is caused by the unexpected phenomena of non-linear effects and turbulences in societies that are global-local occurrences.

Perhaps, the first evidence of the birth of 'arrow of time' scientific knowledge is expressed in the claim of scientists for critical non-linear reflection. R. Merton acknowledged that science advances by standing "on the shoulders of giants". However, he "adopted the non-linear", and using this method he reflected "the course taken by history in general, by the history of ideas in particular, and, in a way, by the course taken in scientific inquiry as well" [Merton, 1993: xix]. In this case he argued for re-reading, in fact, constant reinterpretation of masters of sociology in the context of time and correspondingly accumulation of innovative scientific knowledge. "I have long argued that the writings of classical authors in every field of learning can be read with profit time and time again, additional ideas and intimations coming fleshly into view with each re-reading. What is to be found in writings of the past is anything but fixed, once and for all. It changes as our own intellectual sensitivities change; the more we learn on our own account the more we can learn by re-reading from our freshly gained perspective" [Merton, 1993: 45]. Merton's sociology of science via such concepts as functions, non-functions and dysfunctions, manifest and latent functions, unanticipated consequences, sociological ambivalence and others helped to deal effectively with many challenges of 'arrow of time' and practically includes its nonlinear effects.

A valuable contribution to the 'arrow of time' scientific knowledge was the idea of scientific revolutions. Their nature was first interpreted by $\mathrm{T}$. Kuhn who put into question the traditional notion of the development of science in a linear accumulation of knowledge putting forward the idea of scientific revolutions [Kuhn, 1970]. According to him, in a specific period of time the content and essence 
of science is defined by a paradigm as a set of principles, categorical apparatus recognized by a group of scientists, but only during a certain historical period that constitutes the particularity of the science's subject matter. However, within some time its members begin to face an increase of anomalies that cannot be explained by the existing theoretical and methodological tools which consequently causes the crisis ending in a scientific revolution and the transition to a new paradigm. Thus, for a certain time there coexist two paradigms with a trend that one dominates as "true". The passage to the scientific development via paradigms evoked additional criticism even the highest-ranking forms of knowledge and the acceleration of scientific knowledge formation.

One more step towards the 'arrow of time' scientific knowledge is connected with the formation of a reflexive social science. There appeared the reflexive sociology that meant a more valid understanding of the becoming complex socium taking into consideration both the reflexivity of objective structures and human agency. The reflexive vision also manifested the intense competitions of scientific schools to move forward in investigating as improvisations as well as game strategies that are typical of knowledge of the reflexive socium. According to P. Bourdieu, scientists began to play certain strategies in the academic field struggle over the truth seeking to achieve victories in the game that influences the knowledge and produces competing social conditions for better scientific results [Bourdieu, 1984]. To succeed, one must innovate in working out new empirical, theoretical and methodological tools. No wonder, the reflexive sociology enhanced a higher synthesis of empiricism and theory. As P. Bourdieu and L. Wacquant put it in The Purpose of Reflexive Sociology, "research without theory is blind, and theory without research is empty" [Bourdieu, Wacquant, 1992]. Bourdieu argued for grasping empirically the appearing social realities in the form of reflexive structures that are produced and reproduced through reflexive agency of people. The agency produces both intentional and unintended consequences and becomes the factor of unsynchronised emergence. If traditional people's actions resulted on the whole in intentional consequences and the establishment of synchronized structures and their functions, the agency due to its reflexive nature produces uncertainties and thus side-effects. The reflexive sociology studies how the actors are increasingly getting out of the structural constraints of social systems that previously quite rigidly determined their functional capabilities. The nature of social actors' functionality 
is practically limited only, according to P. Bourdieu, by their habitus [Bourdieu, 1990].

Another representative of the reflexive sociology is A. Giddens who describes the changes in knowledge in the contest of 'institutionalized reflexivity'. According to him, social actions become knowledge-dependent both on the previous social practices based on common knowledge as well as scientific and expert knowledge [Giddens, 1990]. As a result, on the one hand, people are liberated from structures, but on the other - they meet more complex emergent uncertainties. He puts it: "What I call 'manufactured uncertainties' is bound up more with the advance of knowledge than with its limitations" [Giddens, Pierson, 1998: 105]. So, the 'manufactured uncertainties' force people to rely on institutionalized reflexivity to pass over to a system of trust based on the knowledge that the existing institutions would function in accordance with their expectations.

Thus, though reflexivity was studied by M. Weber and G. Simmel as a feature of social interaction, the reflexive sociology represents the problem in a new vision - it mainly deals with the knowledge of reflexivity and its unsynchronised emergence that has never before been the particular subject of investigation. It also studies the unanticipated consequences of the agency that have greatly increased under the effects of 'arrow of time'. For example, Z. Bauman pays attention to the fact that some human reflexivity lacks its proper humane characteristics. In the essay As the birds do he metaphorically compares human reflexivity with the birds' one arguing that 'Twitter' is what birds produce when they tweet. Tweeting plays two roles in the life of birds: it allows them to keep in touch with each other, and to prevent other birds from transgressing on the territory they've made their own. Human Twitter has the same functions: "Once faceto-face contact is replaced by a screen-to-screen variety, - Bauman writes, - it is the surfaces that come in touch. Courtesy of Twitter, 'surfing', the preferred means of locomotion in our hurried life of instantly born and instantly vanishing opportunities, has finally caught up with interhuman communication. What has suffered as a result is the intimacy, the depth and the durability of human intercourse and human bonds" [Bauman, 2011:18, 19]. The lack of the humane is also expressed in 'moral insensitivity', 'heartless kind of behaviour', 'simulating friendship' that is "artificially induces or selfadministrated with the help of painkillers". Z. Bauman and L. Donskis write that "the function of pain to be an alert, a warning, and a 
prophylactic tends to be all but forgotten, however, when the notion of 'insensitivity' is transferred from organic and bodily phenomena to the universe of interhuman relation, and so attached to the qualifier 'moral'. The non-perception of early signals that something threatens to be or is already wrong with human togetherness and the viability of human community, and that if nothing is done things will get still worse, means the danger is lost from sight or played down for long enough to disable human interactions as potential factors of communal self-defence..." [Bauman, Donskis, 2013: 13,14].

We'll also mark two more unsynchronized emergences evoked by 'arrow of time': 1) the speed of acquiring knowledge, which is known to be the 'knowledge as power' [Foucault, 1976] performing the function of change, is much greater than the development of humanistic orientation in our reflexivity. Without the proper humane ethics the knowledge as power is very often opposed to the civil society and even destroys it (the above mentioned by F. Welz the Occupy protests, the social uprising in the Arab Spring, etc. were born by new knowledge about 'happy life' and 'justice'). As one can see the agency based on the rapid speed of acquiring knowledge unsynchronizes individual 'liberation' and humanism; 2) in the agency of individual and collective actors there is yet little knowledge and also realization that we are dealing with the management of the nonlinear developing social systems - people live not in one and the same, but in many different tempo-worlds. So, the 'arrow of time' scientific knowledge rejects simple pragmatic solutions of the challenges of the unanticipated consequences that are produced by reflexivity and unsynchronized emergences - humane approaches are needed.

In the context of 'arrow of time' the dynamics of knowledge is becoming more accelerated and more complex than it was even relatively recently. Firstly, the scientific revolution is essentially gained a permanent character which implies simultaneous coexistence of a variety of competing paradigms. There appeared the 'sociology of sociology' [Gouldner, 1970] actually studying its multiparadigmatic character. It is one of the most rapidly developing brunches of sociology [Ritzer, 2001]. Actually we see the appearance of new and new integrative paradigms taking the form of 'turns' that manifest quite new relations of sociology with other sciences. Thus, U. Beck has worked out a 'cosmopolitan turn' [Beck, 2004] or 'cosmopolitan sociology' that refers to a new way of dealing with cultural differences - in contrast to universalism, nationalism, multiculturalism, "it makes the inclusion of others a reality and/or its maxim... In the 
normative sense (of 'maxim'), cosmopolitanism means recognition of cultural otherness, both internally and externally" that "the national outlook could ignore" [Beck, 2010: 56, 57]. J. C. Alexander has proposed a 'cultural turn': "As compared to the sociology of culture, he writes, - cultural sociology depends on establishing this autonomy, and it is via such a strong program that sociologists can illuminate the powerful role that culture plays in shaping social life" [Alexander, 2003: 13]. British sociologist J. Urry has proposed three new turns in sociology. The 'complexity turn' means that "the complex systems world is a world of avalanches, of founder effects, self-restoring patterns, apparently stable regimes that suddenly collapse, punctuated equilibria, 'butterfly effects' and thresholds as systems tip from one state to another" [Urry 2003: 237]. Order and chaos, he notes, are in a certain state of balance "where the components are neither fully locked into place but yet do not dissolve into anarchy. They are "on the edge of chaos"' [Urry 2003: 238]. This is a fundamentally new view on social order and the vulnerabilities to it. According to T. Parsons, the hierarchy of values and norms that embraces all the levels of society involves the mechanisms that are in a case of any deviations effectively restore the 'social equilibrium' [Parsons, 1960]. Hence, now the situation is being changed: under the conditions of the complexity the efforts to restore the social order almost always generate further unsynchronised emergences and unanticipated consequences pushing the socium away from the social equilibrium. Urry's 'mobility turn' presupposes that new appeared mobilities do not only reduce the social distance and time for the people living in different regions of the world, but put even places on the increasing move [Urry, 2008: 253-270]. At the same time, the mobilities are ambivalent in character - they produce as great advantages as well as new vulnerabilities concerning the increase of mobility of knowledge and the growth of 'manufactured uncertainties'. We consider that the humanity might come to the threshold of actual human capacity of reflection transient events that is to act adequately, rationally, and most importantly - to make decisions based on humane purposes. Urry also argues for a 'resource turn' in sociology, "whereby societies should be examined through the patterns, scale of their resource-dependence and resourceconsequences" and in this case he examines "a new trend of thinking about the future of societies" which he terms "the new catastrophism" [Urry, 2011: 16, 36]. Though K. Marx and M. Weber were aware of resource-dependence, on the whole sociology was 
resource and climate-blind. Among other latest 'turns' in sociology we may name the following: 'materialistic turn' [Latour, 1999], 'practice turn' [Schatzki, Knorr-Cetina, von Savigny, 2001], 'spatial turn' [Gregory, Urry, 1985]. All of them state limits of scientific knowledge of the existing sociological paradigms and are based on theoretical synthesis and multidisciplinary. These turns manifest a principally new move toward 'arrow of time' scientific knowledge.

Secondly, the very pluralism of competing paradigms, their short lives practically excludes the domination of one of them even for a short period of time. Besides, "the will to truth" is also becoming more complex as the criteria of true and false, norm and anomie are subjected to diffusion. Using the expression of Ulrich Beck we may say that many old categories become terms of "zombie science of the national outlook" [Beck, 2007: 112]. For example, today it is almost impossible to imagine anomie as "pathological" forms of social facts limited to specific social space and time, opposing the "normal" forms of social facts.

Thirdly, in scientific knowledge there has entered scientific nonknowledge. Speaking about the catastrophe in Chernobyl U. Beck argues: "The nuclear explosion was accompanied by an explosion of non-knowledge... What used to count as knowing is becoming nonknowing, and non-knowing is acquiring the status of knowledge" [Beck, 2010: 116]. Similar "explosions" occur more or less regularly in the social sciences - yesterday's "universal" knowledge in the form "true" paradigm (structure or action-centered sociology) nowadays is "ageing" and becoming scientific non-knowledge. One of the essential characteristics of 'arrow of time' scientific knowledge is a paradoxical combination of various knowledge and non-knowledge.

Fourthly, the process of the formation of new types of sociological imagination is also subjected to 'arrow of time'. Since C. Wright Mills (1916-1962), the founder of the theory of the sociological imagination [Mills, 1959], there have been several attempts to work out a new type of it. Here are only some examples. P. Sztompka's theory of the sociological imagination that is aimed at interpreting reflexive social life in constant dynamics. According to him, the essence of this type of the sociological imagination is innovative, reflexive thinking about social becoming: to consider all social phenomena as a result of social agency; to understand the phenomena hidden behind the surface of the structural and cultural resources and constraints that affect the social life; to take social life in its dynamics, recognition of the huge variety of options and forms of social life [Sztompka, 1991]. S. Fuller 
in The New Sociological Imagination puts forward a new type of theoretical integrity of sociology with "'progressive' sciences of sociobiology, evolutionary psychology, and behavioral genetics". At the same time, the author considers that "we should revisit the aspects of biological research from which the classical sociological theorist originally drew intellectual sustenance. The histories of sociology and biology have been always intertwined" [Fuller, 2008: 29; 80]. U. Beck agues that "we need a new sociological imagination, one that is sensitive to the concrete paradoxes and challenges of reflexive modernity and which at the same time, is thoughtful and strong enough to open up the walls of abstraction in which academic routines are captured" [Beck, 2007: 212]. The pass from one to another type of the sociological imagination works for the production of innovative accelerative knowledge as there is a codependence of sociological theorizing, thinking, and imagination.

Fifthly, the rise of the network society increases the diversity of scientific schools and especially 'invisible colleges' on a global level, but the scientific consequences of it are being developed non-linearly in space and time. "Now, the most strategically important observation for an analysis in terms of spatial networks is, - $\mathrm{M}$. Castells writes, - that these global networks do not have the same geography; they usually do not share the same nodes... The global network of scientific research does not overlap with the networks of technological innovation. That is why so many are surprised by the failures of projects aimed at developing new Silicon Valleys around a new university" [Castells, 2010: xxxviii]. The network society does not exclude the difference in scientific nodes - there is coexistence of global scientific dynamism with scientific marginality. Besides, scientists live and work in different social times and tempo-worlds, some pass over to 'timeless time' - "it is the time of power in the network society" [Castells, 2010: xlii], while others still continue to be in the nation-based time and work with categories and concepts within the national outlook. As a result, many scientists in the world identify themselves rather with national than with cosmopolitan science and knowledge.

All these examples that could be continued manifest the non-linear increase in the production of knowledge via the pass over to the 'arrow of time' scientific knowledge with all its spatial and time paradoxes, functional ambivalences, global and local metamorphoses that in fact represent scientific 'ordered chaos'. These realities change as the essence of the field of science as well as the strategic rules in it. 
Modern scientists are put in terms of creative innovation, that is necessary to choose constantly not only from various knowledge, but take into account non-knowledge, factors of changes in such resources as types of thinking and imagination, otherwise there is a risk to be on the periphery of the field. This tendency is especially evident in social scientists which theoretical and methodological tools are "ageing” particularly quickly. 'Cognitive conduits' (R. Merton), referring to spreading of ideas over time, lose their role to be long-living references. Besides, the consequences of choices are very difficult to predict, they are ambivalent as the results vary in the cosmopolitization of space and acceleration of time. The particular choice might be good and effective for a career of a scientist, but bad for seeking to move toward more valid knowledge. The attempts to escape from the effects of 'arrow of time', return to traditional authoritative manner of creativity and domination of one 'universal' paradigm do not eliminate the realities of the becoming complex socium by itself. of course, a partial reversibility of evolutionary processes may take place in the complex socium that influence the order/chaos relations in sciences.

At the same time, it is important to note that the above mentioned paradoxes, ambivalences and metamorphoses are not an absolute evil for the development of sciences. Holistic scientific knowledge with persistent references and long-living 'universal' theories cannot be good for a modern 'liquid society' (Z. Bauman) its optimal functioning within the effects of 'arrow of time'. Scientific monism is a utopian vision of the future development of sciences and their knowledge. We need not confront but accept the scientific 'ordered chaos' in the 'arrow of time' scientific knowledge though here appears a very important challenge as to the destiny of scientific knowledge as well to mankind. Under the consequences and effects of the 'arrow of time' scientific knowledge the task of scientists is to explore and define the 'edge of chaos' in complex systems including the system of nowadays scientific knowledge. It becomes an ethic and life-defending imperative not only to transgress the 'edge of chaos' but not to overcome the edge of the very complexity in the 'arrow of time' scientific knowledge. To estimate and fulfill this imperative requires a qualitatively different scientific and social diagnosis than the humanity had before with the participation in it the representatives of social and hard sciences as well as humanities. One of the bifurcations of the 'arrow of time' scientific knowledge might end, as a hypothesis, in the pass over to the type of knowledge that we have named as complex hyper-knowledge meaning 
scientific disordered, chaotic knowledge that goes out of the men's control, produces unpredictable turbulences in scientific and technological innovations and increase in 'normal accidents'. Until recently, scientists tended to find causes of disasters among external factors such as natural processes or human activities. Ch. Perrow who introduced the concept of 'normal accident' shows that disasters are gaining an increasing complexity. Now they might be caused by internal factors generated by natural (normal) interaction of people with complex systems. In the complex hyper-knowledge internal factors may function out of the men's control producing latent disasters. As Perrow states, given the system complex characteristics, the "multiple and unexpected failures are inevitable" [Perrow, 1999: 5.]. In the new book The Next Catastrophe: Reducing our Vulnerabilities to Natural, Industrial, and Terrorist Disasters he demonstrates that vulnerabilities become increasingly complex in their nature: "concentrations of hazardous materials, populations, and economic power in our critical infrastructure make us more vulnerable to natural disasters, industrial/technological disasters, and terrorist attacts" [Perrow, 2011: vii]. The only way to minimize the risk, according to the sociologist, is by abandonment of complex systems. "Normal Accident Theory (NAT), - Perrow states, - argued that if we had systems with catastrophic potential that might fail because of their complexity and tight coupling, even if everyone played as safe as humanly possible, these systems should have been abandoned. Catastrophes would be rare, but if inevitable, we should not run the risk" [Perrow, 2011: xxii.]. Certainly, complex systems in general and complex systems of scientific knowledge in particular in the forms they exist nowadays produce new vulnerabilities for humanity. But we find the idea utopian to abandon them as such. Risks of 'normal accidents' should be minimized not by way of the abandonment of complex systems but rather through their comprehensive humanization that would let them aquire new forms - humane-based development on the basis of cosmopolitan integrity of social, hard and humane sciences. To this synthesis social and religious knowledge should be added as it preserves traditions and conservative way of thinking that might balance or even prevent risky innovations and turbulences (the production of knowledge in human genetics, new means of conducting wars that go out of the men's control).

One of the main problems of the 'arrow of time' scientific knowledge is that scientific innovations implemented in the context of globalization are partially structured and only on a national level. 
They have undoubtedly programmed for intended, desired results, which make the life of the modern man more comfortable. However, in an accelerated manner "collateral damage" [Bauman, 2011] and unpredictable consequences appear that are often highly dysfunctional for knowledge development and even for societies. This presupposes the need for human decisions with humane character. There are at least three basic grounds for them:1) Up to now the institutional regulation of scientific knowledge production is supported by many societies allowing not to overstep the edge of chaos; 2) The becoming 'arrow of time' scientific knowledge brings a fundamentally new interdependence of scientists manifested in a variety of relationships which content may be expressed as in strong ties suggesting their intensive interactions as well as weak ties. The weak ties are of particular importance in 'small worlds' of scientists, because they form network 'invisible colleges' partially covering each other and extend their connections with other networks of scientists. The total effectiveness of the 'small world' depends not only on increasing the number of arithmetic nodes included in it, but on increasing the social space in which a certain number of its members are involved. This confirms the truth that in complex network systems, which include various 'small worlds' weak ties can have a great impact on the very humanization of scientific and technological innovations as they presuppose particular network private insurance; 3) the subject matter of many sciences is being changed in humane direction: more and more scholars pass over to the problems of unpredictable turbulences, climate change, global risks treating them as a matter of life and death of humanity.

To develop the 'arrow of time' scientific knowledge in humane direction we argue for a humanistic turn in sociology, whereby societies should be examined through the patterns and character of their complexity-dependence and human agency-consequences. This implies a newer type of scientific thinking and imagination based on the synthesis of social, hard and humane sciences. In the most general way, the humanistic turn deals with the acceleration of socio-cultural dynamics and social complexity, synergetically takes into consideration paradoxical synthesis, risks, and dispersions of socium, searching for new forms of humanism, based on men's existential needs. It specially studies the problems of humanization of scientific and technological innovations to maintain the balance between them and key environmental processes so that the advance of knowledge would produce as much as possible controlled 'manufactured 
uncertainties'. Under these realities the concept 'knowledge as power' should be rediscovered and mean humane knowledge creating new contexts for humane actions.

REFERENCES Alexander, Jeffrey C. (2003). The Meanings of Social Life. A Cultural Sociology. Oxford University Press.

Bauman, Z. (2011). 44 Letters from Liquid Modern World. Cambridge: Polity Press.

Bauman, Z. (2011). Collateral Damage. Social Inequalities in a Global Age. Cambridge: Polity Press.

Bauman, Z., Donskis, L. (2013). Moral Blindness. The Loss of Sensitivity in Liquid Modernity. Cambridge: Polity Press.

Beck, U. (2004). The Cosmopolitan Turn // N. Gane (ed.). The Future of Social Theory. London: Continuum.

Beck, U. (2007). Risk Society Revisited: Theory, Politics and Research Programmes. // The Risk Society and Beyond. B. Adam, U. Beck, J. van Loon (eds.). L.: Sage Publication.

Beck, U. (2010). World at Risk. Cambridge: Polity Press.

Bourdieu, P. (1984). Homo Academicus. Stanford, CA: Stanford University Press.

Bourdieu, P. (1990). In Other Words: Essays towards a Reflexive Sociology. Stanford, CA: Stanford University Press.

Bourdieu, P., Wacquant, L. The Purpose of Reflexive Sociology (The Chicago Workshop) // P. Bourdieu, L. Wacquant (eds.). An Invitation to Reflexive Sociology. Chicago: University of Chicago Press.

Castells, M. (2010). The Information Age: Economy, Society and Culture. Volume I: The Rise of the Network Society. Second edition. Oxford: Wiley-Blackwell.

Foucault, M. (1976). The Archeology of Knowledge and The Discourse of Language. New York: Harper Colophon.

Giddens, A. (1990) The Consequences of Modernity. Cambridge: Polity Press.

Giddens, A., Pierson, Ch. (1998). Conversations with Anthony Giddens: Making Sense of Modernity. Cambridge: Polity Press.

Gouldner, (1970). A. The Coming Crisis of Western Sociology. New York: Basic books.

Gregory, D., Urry, J. (eds.). (1985). Social Relations and Spatial Structures. London: Macmillan. 
Kuhn, T. (1970). The Structure of Scientific Revolutions. Chicago: University of Chicago Press.

Latour, B. (1999). Pandora's Hope. Essays on the Reality of Science Studies. Cambridge.

Merton, R. K. (1993). On the Shoulders of Giants. Chicago and London: University of Chicago Press.

Mills, C.W. (1959). The Sociological Imagination. New York: Oxford University Press.

Parsons, T. (1960). Structure and Process in Modern Societies. New York: Free Press.

Perrow, Ch. (1999). Normal Accidents: Living with High-Risk Technologies. Princeton: Princeton Univercity Press.

Perrow, Ch. (2011). The Next Catastrophe: Reducing our Vulnerabilities to Natural, Industrial, and Terrorist Disasters. Princeton University Press.

Prigogine, I. (1997). The End of Certainty. New York: Free Press.

Ritzer, G. (2001). Explorations in Social Theory. From Metatheorizing to Rationalization. London, Thousand Oaks, New Delhi: Sage Publications.

Schatzki, T.R., Knorr-Cetina, K., and von Savigny, E. (eds.). (2001). The Practice Turn in Contemporary Theory. London: Routledge.

Sztompka, P. (1991). Society in Action: A Theory of Social Becoming. Cambridge: Cambridge University Press.

Urry, J. (2003). Global Complexity. Cambridge: Polity Press.

Urry, J. (2008). Mobilities. Cambridge: Polity Press.

Urry, J. (2011). Climate Change and Society. Cambridge: Polity Press.

Welz, F. The theme: Crisis, Critique and Change // Programme Book. ESA 2013, Torino. Crisis, Critique and Change. $11^{\text {th }}$ European Sociological Association Conference. 28th - 31st August, 2013. Turin - Italy. 
СЕРГЕЈ А. КРАВЧЕНКО

МОСКОВСКИ ДРЖАВНИ УНИВЕРЗИТЕТ ЗА МЕБУНАРОДНЕ ОДНОСЕ

ДЕПАРТМАН ЗА СОЦИОЛОГИЈУ

РУСИЈА

РЕЗИМЕ

РАЂАЊЕ НАУЧНОГ САЗНАҢА О „СТРЕЛИ ВРЕМЕНА”

Овај чланак анализира последице „стреле времена”, изражене у настајућем сложеном социјуму, последице које представљају нове изазове за постојећа знања. Аутор доказује да ефекте „стреле времена” треба проширити и на нелинеарну динамику научног сазнања уопште, а социолошког нарочито, сматрајући да је научна спознаја „стреле времена” настала и заснована на новој научној синтези. У том погледу, овде су анализиран и „преокрети у социологији" - квалитативне промене у спрези са другим наукама, чије се спознаје позајмљују - као посебан термини, као и концепти, који су испуњени савременим социолошким садржајем. Аутор види одговор на постављене изазове у хуманистичком преокрету који подразумева синтезу друштвених и природних наука, и њихов развој кроз трагање за новим видовима хуманизма заснованог на људским егзистенцијалним потребама.

КљУчнЕ РЕчИ: друштвена и културна динамика, „стрела времена”, друштвени комплекс, турбуленција, рефлексивност, нелинеарност, научног сазнање, знање, хуманистички преокрет. 